Mukaddime, 2021, 12(1), s. 27-44.

DOI: $10.19059 /$ mukaddime.860918

\title{
Tender Mothers: Breastfeeding, Wetnursing, and the Limits of Social Critique From the Late Ottoman to the Early Republican Periods (1880-1930)
}

Cem DOĞAN ${ }^{1}$

\author{
"Do not go against nature, \\ Breast-feed your baby!" \\ (Servet-i Fünûn, 1927)
}

\section{Müşfik Analar: Geç Osmanlı'dan Erken Cumhuriyet'e Emzirme, Süt Annelik ve Toplumsal Eleștirinin Sınırları (1880-1930)}

Öz

Süt anneliğin tarihsel arkaplanı MÖ 200o'li yıllara dek uzanmaktadır. Süt annelik, köken olarak göğüslerinde süt olmaması nedeniyle bebeklerini besleyemeyen kadınların özel ihtiyacından kaynaklanıyordu. Anne sütü, bebek mamalarının keşfedilmediği bir dönemde yenidoğanların sağlığı üzerinde önemli bir etkiye sahipti. Lakin süt annelik uzun vadede bir meslek biçimine dönüștü ve süt şişeleri gibi 19. yüzyılda uygulanmaya başlayan yöntemlere gelene kadar varlığını korudu. 20. yüzyılın başlarında süt annelik yeni bilimsel gelişmeler karşısında çoktan gözden düşmüş ve toplumsal eleştirinin beslendiği kaynaklardan biri haline gelmişti. Tıbbi tavsiyelerle dolu popüler literatürün yanı sıra kentli orta sınıfın toplumsal farkındalığının temellerini atan aydınlar sık sık Türk kadınlarının haneiçi işlerden uzaklaştığı yolunda eleştiriler getirmekteydiler. Bu dönemde, toplumsal eleştirinin tonu normatif cinsiyet rolleriyle iç içe geçmiş ve merkezileşme öne çıkarılmıştı. Ayrıca süt, İslam hukukuna göre aileler arasında akrabalık yaratabilir ve süt kardeşleri arasındaki evlilik veya miras gibi konularda ciddi toplumsal sorunlara yol açabilirdi. Bu makale dönemin popüler literatüründen faydalanarak geç Osmanlı ve erken Cumhuriyet dönemlerinde emzirme ve süt annelik uygulamalarını cinsiyet rolleri bağlamında analiz etmeye çalışmaktadır.

Anahtar Kelimeler: Osmanlı Devleti, Süt annelik, Emzirme, Annelik, Toplumsal Cinsiyet.

1 Dr. Öğr. Üyesi, Iğdır Üniversitesi Fen Edebiyat Fakültesi Tarih Bölümü, dogancem1@hotmail.com, ORCID ID: 00oo0002-2008-3830. 


\begin{abstract}
The historical background of wet-nursing dates back to ancient ages as early as 2000 BC Wet-nursing originally arose from a peculiar demand in milk for those who were not capable of producing it for their babies because of the milk shortage in their breasts. Mother's milk has played a significant part in the health of neonates in the absence of infant formulas. However, wet-nursing took the shape of a line of work in the long term and kept its existence until the rise of the 19th century's new infant feeding practices, such as milk bottles. At the turn of the 2oth century, wet-nursing has already been in disfavor against contemporary scientific developments and also turned into a target of social critique. Popular literature of medical instructions and the intelligentsia who provide the social consciousness of the urban middle classes every so often expostulated that Turkish women abstained from domestic tasks. The essential character of critique intertwined with the normative gender performances and evoked the voice of centralization. Furthermore, wetnursing used to function in creating kinship between families according to Islamic tradition and might have caused acute social complications, like the marriage between milk siblings or inheritance issues. This article tries to analyze the breast-feeding and wet-nursing practices in the late Ottoman and early Republican periods in the context of gender roles through the popular literature of the period.
\end{abstract}

Keywords: Ottoman Empire, Wetnursing, Breastfeeding, Motherhood, Gender. 


\section{Introduction}

We are apt to assume that politics is not a field of interest for an average person because it is associated with a higher specialized affair that requires only some specific people called politicians. We also think that we are affected by politics just in the time of elections or when we have to pay our taxes (Tiger ve Fox, 2017: 24). However, as Foucault (1982: 782) reveals in one of his works, the instruments of subjection cannot be investigated outside their relationship to the structures of exploitation and oppression. But they do not simply establish the "terminal" of more significant systems. They entertain complex and circular relations with other forms. So, the term "gender politics" might seem awry to us at first, but if we lay it in the proper context, it would be a useful means to appreciate the inter-relational network of power and its impressions over the community.

A vital aspect of the perception of womanhood is that it permits us to investigate the category of women. We can observe 'women' as a harmony of which composed through an elaboration of connotations assigned to particular physical characteristics (Carter, 1995: 32). Concordantly with this argument, one of the late Ottoman and early Republican discussion was based upon the discourse of naturalness about motherhood and its relations with child care. In this discourse, nature had created women as mothers, and for this very reason, every woman had to fulfill their primary duties. The first lesson for women was to feed and grow her child as a healthy person, and be an exemplary mother, but not to be an engineer, doctor, or chemist (Zeki, 1928: 8).

As Sharon Hays (1996: 97) conceptualized under the title of "intensive mothering", society has a set of anticipations of a mother that she should take the full responsibility of taking care of her own children unselfishly. She also must spend most of her time with the parenting activities and always put the needs of her baby before her own. There is no doubt that the social role for a woman in the late Ottoman and early Republican periods was "intensive motherhood", and breast-feeding had a great potential to fictionalize the zone of being a proper woman to a certain extent. Thus, mothers those who denied to breast-feed their infants were the major objects of social critique because they were not "natural". Gender-based criticism stepped in defining the framework of ideal motherhood and the triangle of motherhood/breastfeeding/wet-nursing was its inseparable part.

The main argument of this article is to demonstrate that breastfeeding was a subtle catalyzer which propounds the changing face of breasfeeding practices in the late Ottoman and early Republican periods. Mother's milk had a particular and binding function in Ottoman society, such as creating kinship and being a regulative mechanism in traditional Muslim lifestyle. However, the meaning of breastfeeding transformed into a debate of medical professionalism as well as an anti-modernist discourse through the criticism of social duties of 
women and the limits of motherhood. Paradoxically, those who brought criticism on the subject were composed mostly of the modernizer actors themselves. They neither intended to let go of the traditional place of women in society, nor take any responsibility for the metamorphosis in the social roles. In the final analysis, breastfeeding was seen a means of creating a healthy offspring but it was supposed to be executed under the certain circumstances that could not cause defiling the deep rooted gender roles in society.

\section{The Power of Milk: Wet-nursing and Kinship in Islamic Tradition}

Throughout the ages, mother's milk has been regarded as the perfect nourishment for infants. However, there are plenty of cross-cultural discrepancies and conflicts, too, linked with maternal breastfeeding around the world (Cassidy ve El Tom, 2015: 2). Because, as MacClany puts it, milk is a unique universal. Milk is the sole common foodstuff that is produced by the human body, for the benefit of humans. It is also the mere feed every mother produces, the particular meal every individual consumes at the takeoff of their life (MacClany, 2003: 163). What makes mother's milk more valuable, though, is the fact that it is not only limited to an unmatched food, but it is also could be produced by the woman for a certain period. Until the presentation of hygienic cow's milk, human milk was of crucial value to a newborn; it is not shocking thus that wet-nursing involves a long past (Hill vd., 1987: 183).

No matter how breastfeeding practice is not typical to see in these days, there was a time in which people used to deem their kin of milk worthy as the blood agnatic. In this sense, families and establishments have hired wet nurses to breastfeed infants whose mothers abandoned them or refused to feed them, as of ancient times. Some fourth century documents by Oribasius repeated information from earlier texts from the Hippocratic, Greek, and Roman cultures, some of which are no longer available, and synthesized this knowledge with his own opinions. The wet nurses of antiquity were ordinary mothers, coming from the poor social classes than the hirer, and the wet nurse used to earn a considerable amount of money. When the family accepted to employ a slave woman as a wet-nurse, they paid the service charge to her master (Thorley, 2008: 26).

While the Greek writer Lucius Mestrius Plutarchus (AD 46-119/120) pointed out that a sentimental connection was formed between mother and baby through breastfeeding, physician intellectuals such as Favorinus and Soranus showed that there was a solid liaison between mother's milk and the personality with the character development of the child (Utku, 2020: 58). In his manuscript De re Medicina, Aulus Cornelius Celsus noted that diarrhea 'carries off mostly children up to the age of ten', which shows that the high infant mortality percentage was perhaps because of hand-feeding. If a mother could not feed 
her own baby, perhaps if she was extremely weak following the due or if she found the whole notion repulsive, then a healthier option to hand-feeding was the hiring of a wet nurse (Brown, 2004:41).

During the Middle Ages, society considered childhood as a particular stage of frailty and susceptibility. Breastmilk was believed to own miraculous characters, and breastmilk could carry both physical and mental peculiarities of the wet nurse (Stevens, Patrick ve Pickler, 2009: 33). What makes the difference between the Western and Eastern tradition in terms of wet-nursing institution, at this point, is that this practice has an obvious ability of shaping social relations in the East, while it establishes more or less an economical and medical web of connections in Western cultures. In the West, indeed, the notion of milk-kinship righteously astonishes the people. Because no medical or scientific curricula put a debate on the concept of creating such a liaison. Yet in the Muslim world, most notably in the Arab countries, milk-kinship is a social phenomenon and has always been a popular subject among the scholar circles. In pre-modern ages, women living in the same house or locale would nourish each other's infants as a requiring or acquisition was demanded. What is more, professional wet-nurses were accessible for urban and upper-class women (Bawany, Mildan ve Padela, 2016: 49).

Breastfeeding and wet-nursing as one of nourishment style has its grassroots on a theological baseline in Islamic tradition, which assists the recruitment of a wet-nurse with reciprocal agreement from the parents when the mother is incapable of suckling her baby (AlHreashy, 2018: 195). However, an affinity will be called into being from the very occurrence that the baby begins drinking milk from the bosoms of his/her wet-nurse. This might not suggest a blood relationship, even though connotes a major influence in the composition of the bonds between two families; wherefore one could probably not understand what it means to the Eastern/Islamic tradition compared to the West.

According to the shari'ah, kinship means an organization based primarily upon blood relationships and the establishment of marriage. Family bonds are determined by the manifestation of biological origin or an Islamic marriage (nekah), both of which are essential experiences that shape the religious obligations of close and extended family members. One such liability is in conjunction with the Islamic framework of mahramiyat. Mahramiyat refers to a framework of social relations grounded on lineage and marriage that coordinates and sanctions the legitimacy of marriages and mutual effects with the opposite sex. The codes of intimacy, thus, categorize people of the converse sex as mahram and non-mahram (Rahbari, 2020: 43). As Bouhdiba signified (2008: 16-17), the same restrictions to marriage are generated by suckling between newborns on the one hand and the wet-nurse on the other, and the 
whole of her family. Children suckled by the same wet-nurse are considered as brothers and sisters, even if they have not suckled together.

The link by wet-nursing, on the other hand, creates a block to marriage as in the kinship of blood. Regarding blood relatives, an individual is forbidden from marrying any lineal heir, any genetic ascendant, any offspring of his or her parents, and the actual child of any grandparent. Relation through marriage, or kinship, raises the limit to marriage between a person and the partner of any ascendant, the mate of any heir, any ascendant of his or her partner, and any offspring of his or her partner. A foster relationship also emerges when a woman breast-feeds someone else's baby. It produces a hinder to marriage not simply between stepbrothers and sisters but also between the foster mother and all her relatives on the one side and her foster children, their spouses, and their heirs on the other (Coulson, 1971: 14).

Breastfeeding institutes in Islamic Law, under peculiar requirements, an optional and non-biogenic kinship relation known in Arabic as ridā' or radā'. This kinship is inclusive of the rank of constant grounds in which prevent marriage in Islamic tradition. When a woman breast-feeds an infant boy, she becomes as if she is his actual mother and thus, he can not marry her or her relatives as her mother, daughters, or sisters. Similarly, the breast-feeding woman may not marry her nursling boy or his children and grandchildren anymore (Ghaly, 2012: 120). And, to form a tie by nursing, one drop of suckling during the initial twoand-a-half years of one's life would be sufficient (Schacht, 1982: 162).

Furthermore, the inhibition of marriage between milk-relatives is not only a cultural tradition, but a religious and exact ban to Muslims. Al-Qur'an remarks it in particular by the surah an-Nisâ (4: 23): "Prohibited to you (for marriage) are: your mothers, daughters, sisters, father's sisters, mother's sisters, brother's daughters, sister's daughters, foster mothers (who gave you suck), foster sisters..." (Al-Qur'an, 1937: 186). As it is seen in the Quranic command, marrying with a milk-relative is clearly forbidden by God himself.

\section{Breast-Feeding and Politics of Demography}

Until the late 19th and early 20th centuries, the vast majority of children received their nutrition at the breast; because many people considered bottle feeding a death warrant for the unfortunate baby whose mother could not, or would not, breastfeed; and just a few physicians concerned themselves with child feeding. Mothers who decided not to breastfeed their infants relied upon wet-nurses, or they prepared paps or cow-milk cocktails from recipes recorded in textbooks or supplied by acquaintances and relatives. During the second half of the century, worry about the significant rate of infant mortality stimulated interest in the dispute of infant feeding, since plenty of infant deaths were 
attributed to poor nourishment, owing either to insufficient breast milk or to artificial food of poor quality (Apple, 1987: 4).

Apparently, it was a time that childbirth became a whole new area of professionalization and a focus point for the art of new medicine. Like in Borst's (1995: 2) statements, sociologists and historians have set out a certain number of precedents to examine the progress of an occupation toward professionalization. These comprise the standardization of exercising, the formation of a separate and privileged frame of knowledge, the authority over the manufacture of both knowledge and its architects, and most significant, autonomy, namely the ability to deal with the tension between the technical and the indeterminant facets of work. Furthermore, specialists could be characterized as full-time professionals, who practice full-time because their function is their source of revenue. Investigating the shift in childbirth assistants in the late nineteenth and early twentieth centuries is an exceptionally effective means to consider the process of professionalization. Because all human societies count on physicians to elaborate notions of health and wholeness, and claim their proficiency for the benefit of people and societies. The process of "professionalizing" young doctors in medical schools provides society to instruct authorities who are trusted with establishing the schemes of intelligence, the foundations, and the communications needed to maintain and develop the health of individuals and the society at large (George v.d., 2006: 63).

In this context, we may assert that there was an overt synchronism between the Eastern and Western modernisation of standarts in medical circles, and a male dominant perspective in parallel with it. For this reason, it is not shocking to observe that almost all of the standardizing authorities were males, and somehow the debates concerning breast-feeding and wet-nursing at the at the junction point with the anxiety of child deaths and naturally with the politics of population. In the prologue of Ali Vahid [Yaşat]'s Annelere: Memedeki Çocuk Nasıl Beslenir? (To Mothers: How to Feed Sucklings?), for instance, an author of Himâye-i Etfâl Cemiyeti (Turkish Association for Protection of Children) stated that the strength of a nation was measured by the health of its children. The future of a nation that lost seventy percent of its sickly infants in the age of suckling was to be desperate ([Yaşat], 1924: 4). Dr. Kadri Raşit [Anday] (1923: 17) wrote in Mihrâb that working classes come into fruition only by the high numbers of population, and if a nation has a crowded working force its voice would be heard louder in the international arena.

This was ostensibly where medicine intersected with the campaigns of demography of the day. In the late Ottoman Empire, population represented one of the ominous concerns, and it meant a legalizing instrument for the state to intervene in the medical realm and organize in facilitating the desired distribution of population in the society. To achieve this objective, state forces and intellectuals who built the medical knowledge brought maternal issues into 
question with regard to its practices. Maternity provided the main conceptual basis as was a crucial debate which speculative factor about birth practices within the spectrum of society.

Another critique on breastfeeding related to population concerns and wet-nursing was suckling the infants by hired women. Dr. Besim Ömer [Akalın] put a particular emphasis on this issue and said that wet-nurses who took a child to breast-feed in their homes sometimes fulfill their duties not with their breasts but with milk bottles, spoons, or slurry formulas. Because of these uninformed ways of nutrition most of the babies perished before their first birthday ([Akalın], 1925: 111). Same author explained that there were two kinds of infant feeding. One of them was "natural feeding" (irza'-yı tabiii), which meant the nutrition from the breasts of mother or wet-nurse, and the other one was "artificial feeding" (irza'-yı sınâi') which shows that the baby was fed by the milk of a cow, a donkey, or a goat ([Akalın], 1892: 69)

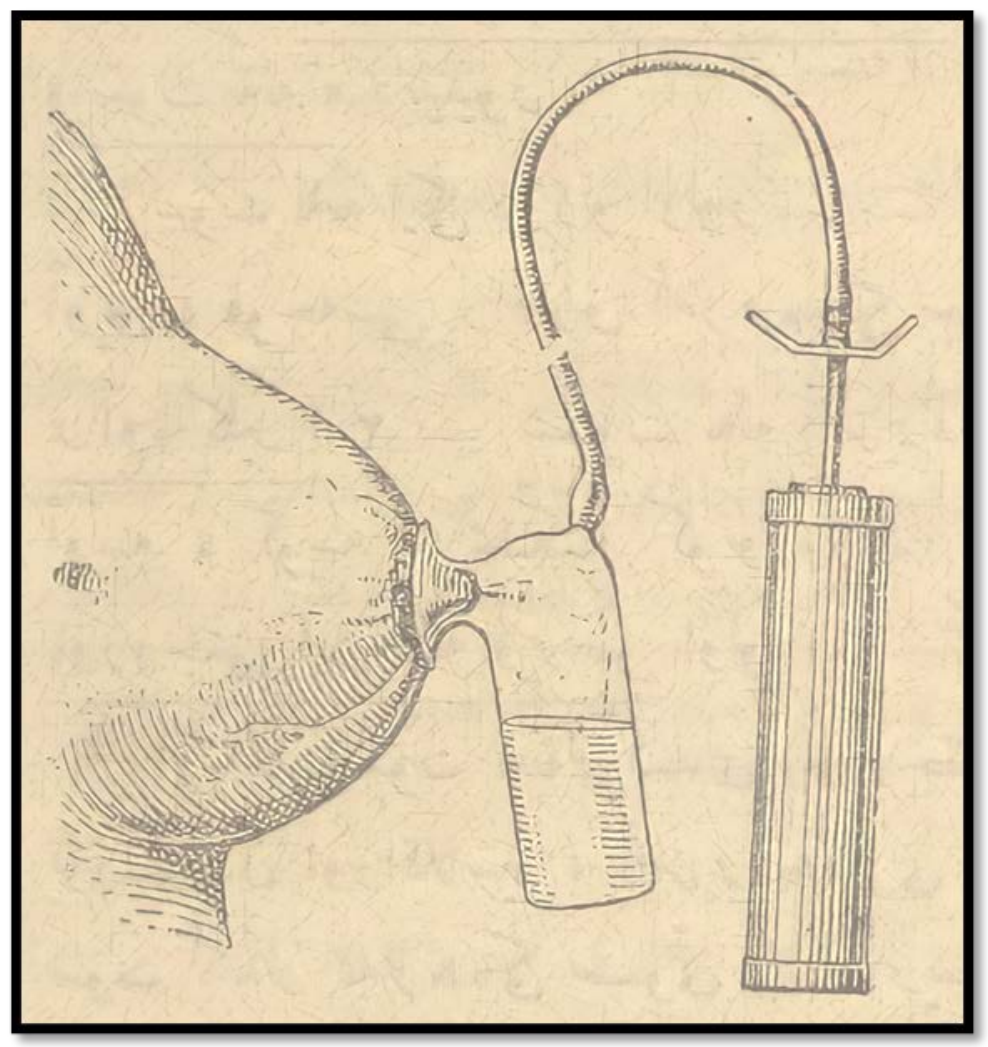

A milk pomp. Source: ([Akalın], 1925: 109). 
Dr. Celaleddin Muhtar [Özden] noted in Servet-i Fünûn that there were some people who provided the service of finding new wet-nurses for the needy families, called hizmetçi kolcusu (guard of maid). However, these people had a pernicious past that was worse than their present, and therefore it was not possible to mention a guarantee about them. He propounded to establish an organization, which would mediate the hiring and returning process of wetnurses and give them a şahâdetnâme (certificate) that was to be showing that they had no diseases. This organization would also submit a report to show that the infants a wet-nurse breastfed and will feed were healty as well (Servet-i Fünûn, 1901: 333).

As a demographical problem, infant feeding became visible in late 19th century Europe. It is easy to guess that the problem was in relation to pediatric anxieties and public health campaigns. Because of the high rates of death among children, medical experts felt obliged to make infant mortality issues their foci (Golden, 1996: 131). This process, however, ended up with a new development in support of capitalism because some European entrepreneurs realized that infant feeding could be shaped as a source of great income.

To exemplify, Henri Nestlé, a Swiss merchant with a passion for chemistry, and a concern in the issue of infant mortality, decided that the solution rested in "placing within the reach of all" the "good Swiss milk" of cows provided on nutritious Alpine grass. For cow's milk differed from human milk in "plastic and respiratory aliments," he mixed milk, sugar, and wheat flour and cooked the wheat with malt to transform the indigestible starch into more easily digested dextrin. Nestlé represented his Milk Food as "good Swiss milk and bread, cooked after a new method of my invention, mixed in proportion, scientifically correct, so as to form a food which leaves nothing to be desired." By the early 1870 s the Nestle's Milk Food Company was circulating its output throughout Europe, Australia, and the Americas (Apple, 1987: 9).

In the late 19th century, almost 30 babies out of 100 born in the United States died before they saw their first birthday (Wolf, 2001: 1). Between 19031915, Ottoman Foundling Asylum (Dâr-ül'aceze) admitted 672 infants between 1- 6 months, but sadly, 500 of them, which corresponds to $74 \%$, did not make it (Maksudyan, 2009: 381). At the onset of the 20th century, infant mortality was at such peaks that organized attempts to strike it began more or less hastily throughout what is now noted as the developed world. In the forefront was western Europe, a great effort having arrived from the French, stung by the loss of the Franco-Prussian War in 1870 and the recognition that community dynamics favored a fresh and unified Germany. (Wegman, 2001: 401).

At the turn of the 19th century, breastfeeding replaced with sterilized animal milk, mostly cow and sometimes goat milk in bottles after the disappearance of wet-nursing. The conflict between the mother and the wetnurse thus left its place to breast-feeding bottle debates. While most people still 
believe that breastmilk is the best solution, few thought it was indispensable for a child to survive. Put it medically; most children born in the West were no longer at risk of death that brought by nurses or unsterilized milk (Yalom, 2002: 229-230). The functionality of mother's milk, on the other hand, preserved its significance for a while. In 1923, for example, Besim Ömer [Akalın] (1923: 65) argued that artifical nutrition (irza'-yı sınâi') played a pivotal role in infant deaths with eighty percent, while the same practice caused death in a percentage of twelve after a couple of breastfeeding, and finally natural breastfeeding (irza'-yı tabiii) was producing the best result with three percent.

\section{Wet-nursing and Maternity from the Late Ottoman to the Early Republican Periods}

In the first volume of the History of Sexuality, Foucault (1978: 104) underlined the fact that there are several points concerning power and the conduction of sexuality. In his opinion, modern medical knowledge turns women's bodies into the objects of hysterization because the woman body refers to the center of reproduction. Therefore, it is open for the population debates, along with being a place in where pedagogical purposes can be experienced so that it becomes a monitor for social control. The mother, thus, with her negative form of hysterical woman establishes the most conspicuous design of this hysterization as a natural outcome of this process.

As it is correspondingly pointed out in Servet-i Fünûn (1894: 370), malnutrition of newborns and the benightedness of mothers in child care led to boost the rates of infant deaths, and there was no probability to reproduce a healthy population in an atmosphere of which mothers are reckless and most of the people escaping marriage. The fundamental way of maximizing the population of the country needed not only to prevent the infant deaths but to decrease it by decent child care and protective health measures (Olcay ve Derviş, 1925: 2). Kadri Raşid [Anday] (1875-1949), touched upon the same subject and said that mothers appealed to the term "evil eye" (nazar) in explaining the child deaths instead of their own laxness. Therefore, they turned the neighbours into enemies and deluded themselves with the idea of fate when their child passed away (Âsâr-ı Nisvan, 1925: 9).

There are many occasions complaining about the "new women" in the newspapers. One of them is published in Sihhat (Santé), under the title of "Suckling of Mother with Wet-nurse and Our Women" claimed that "new women" had no love for their children as the old ones did, because they were fond of promenades and jewellery (Sihhat, 1887: 29).

It is the duty of a mother to defend the political and civil rights and the chastity and dignity of her child and to think about her future. In our country, some women, most of the urban women who have wealth, cast away even their most essential tasks 
which nature has predicted for them; leaving their children in the hands of wetnurses. As soon as the child is born, (s)he falls on an unpleasant, futile ground; $s($ he) hears nothing by his/her native language about the love of nation or civic duties; $s$ (he) grows up deprived of primary education, moral nurture, and sanitary needs, and is mentally, bodily poisoned (Ahmed Rıza Bey, 1908: 272).

The quote above belongs to Ahmed Riza Bey (1858-1930), who was a wellknown member of the Committee of Union and Progress (Ittihad ve Terakki Cemiyeti). In the European societies, public health movements have concentrated on educating women about the favors of breastfeeding, but have neglected to appreciate that communal and material constraint significantly affect women's choices regarding infant feeding (Lee, 2018: 7).

Imperative for the endurance of newborns and the way they grow, breastfeeding was a lot more than simply a biological phenomenon: it was more of a feature of "mothering", the culturally produced bonding between mother and child, which is based on some peculiar practices (Giladi, 1999: 1). Considered in this way, Ahmed Riza's argument makes itself more clear. Despite of being one of the foresighted members of the Committee of Union and Progress, Riza could not help himself to express what he had in his mind on the relationship between motherhood, family, and breastfeeding as a maternal and familial duty.

As a matter of fact, the European intellectuals, too, suggested similar applications and measures to shape a new motherhood and child-raising rules in the society. One of the well-known French gynecologist Adolphe Pinard, for example, thought that "a little institute of child-care (puériculture)" should be assigned to all girls' primary schools. Pinard delivered his initial presentation class in 1903, and by 1909 the textbook that he planned for such classes appeared on the recommended reading lists of about thirty percent of French school precincts. The authoritative text emphasized first the significance of breast-feeding, and second the obligation of mothers to adopt scientific principles rather than conventional methods. "If all mothers did their duty," Pinard concluded, "the mortality of babies would be reduced greatly" (Allen, 2005: 80).

In an analogous way, British intellectuals assumed that the home was a fortress and the ideal woman had a primary caring-duty for it. According to them, home was the source of all comfort, the best evidence of (or substitute for) divine love at a time when the existence of God was increasingly coming into question. And if the home was the heart of the nation, the mother was the heart of the home. In John Ruskin's famous image, she was the queen of the garden, ruler and creator of her miniature Eden, possessor of 'a power, if she would wield it, over [her child], and over its father, purer than the air of heaven, and stronger than the seas of earth' (Holmes ve Nelson, 1997: 1). There is no room to doubt that the most important duties of the British woman were breast-feeding and childcare because she had the real potential to raise healthy 
generations in her own fortress, which was symbolized the very image of the pedagogical aim in the Ottoman thought and education in the day.

The fall of the breast-feeding tradition, if not its elimination, among the metropolitan elites may be considered as an aftereffect of both contemporary feeding routines and altering dwelling types. The accessibility of milk powder, and a transition from the conventional patrilocal agnatic toward neo-local nuclear family house, have shifted the condition in which the tradition previously assisted. Needless to say that one motivation that caused this practice was the basic fact that the factors which held several women together in the same residence or compound served to their breastfeeding the infants of each other (Altorki, 1980: 240).

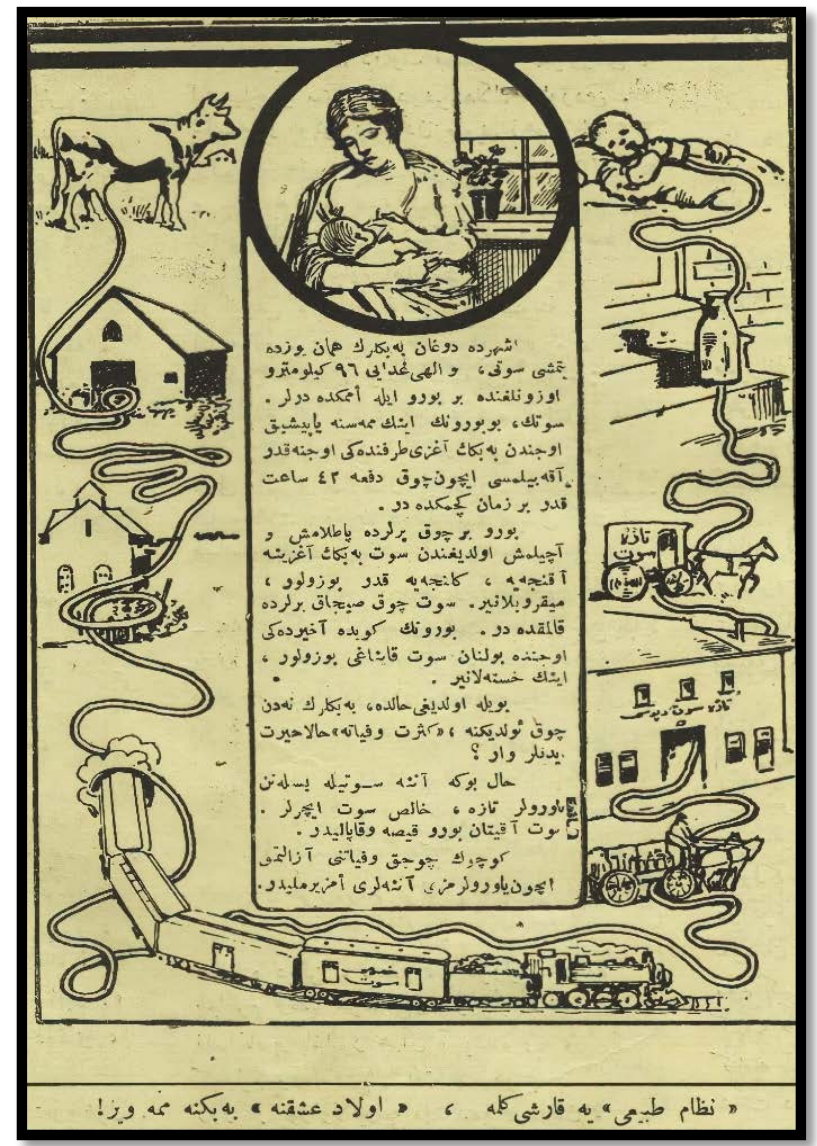

A poster that shows long and short-distance suckling for babies. Source: Servet-i Fünûn, 35 (157-1631), 17 December 1927, s. 5 
Before the overabundance of sick bottle-fed babies, newborn feeding was of slight concern to medical experts. Merely a few doctors who paid attention to orphaned infants in foundling homes gave the matter any conclusion, and their efforts to develop human milk substitutes were rigorously in the interest of motherless kids. It was mother's move from chest to bottlefeeding, and municipal establishments' statistical compilations detailing the amounts of concomitant sick and dead babies, that sparked doctors' participation in cultivating human milk replacements for all babies, not just the unlucky ones without a mother (Wolf, 2001: 3).

Breastfeeding was an action that truly embodied motherhood, on the other hand. Much like pregnancy and childbirth, breastfeeding was a certain indicator of biological distinction and presented a physiologic claim for maternal identification embedded in a secularized and material reality. Despite its intimate character, however, breastfeeding had not always been well reduced to a "fundamentally special experience." In the resurrection of breastfeeding in the decades during and after the "death" of moral motherhood, we may observe the perpetuation of maternal status based upon timeless regard of the moral authority of "the natural" that has insisted well into the contemporary age (Martucci, 2015: 20). One of the emotional aspects of breastfeeding, therefore, in terms of a mother was that it was a shelter for women who had lost their infants. Mothers whose babies had perished experienced their motherhood passions by suckling to another baby, so that they could ease the suffering of their babies to some degree. This practice also relieved the physical pain of the mother by allowing her to drain the milk in her breasts (Tekir, 2019: 862).

Dr. Mehmed Fahri (1900: 3) pointed out in Ikdam that a family who employed a wet-nurse for their newborn should have been truly careful and not neglected to question her previous way of life because it would directly affect the child's progress, both in terms of physically and psychologically. If the wetnurse had poor standards of nourishment, she perhaps was to infect the infant with the illnesses that had embedded in her body. To be certain that the wetnurse was free from any defect, one must have considered several qualities of her. In the journal of Sihhat (Santé), there is a long and detailed list that orderly puts the essential characteristics (evsâf-ı matlûbe) of a proper sütana (wetnurse). First, she had to be between 20-30 ages and it had not been passed over eight months after her due. There had not to be any scars around her neck, axillas, head, and near the nails. As the primary source and mechanisms of milk delivery, the shape of her breasts should have been as in demand, with no scars, floppy, and little nipples. Her gingiva and teeth were to be solid and symmetrical with wide and chubby shoulders. She was not to be menstruated or pregnant. Curiously enough, the counsels go on with the mention of her temperament and declared that she was to be cute, naturally laid-back with a cheerful way of speaking. She likewise had to be experienced in suckling, which means being a mother of several children and aware of how to care for the babies. The woman 
was to be clear in terms of both herself and the child she was breastfeeding. Finally, the family members who intended to hire the woman must have seen with their own eyes that her children were robust (kaviyy'ü-l-bünye) and the family had to be sure that the future-wet-nurse was free of any infectious maladies, like tuberculosis, scrofula, cancer, and particularly syphilis (Sıhhat, 1888: 91).

We also can claim that there were some moral conditions once parents hired a wet-nurse. A proverbial idiom that giving advice to the parents who were in search of a wet-nurse leaves no room to doubt for it. According to this, parents must have been careful in picking a wet-nurse that the father of the woman's own child was to be known because it was an obvious indicator of her moral condition. Besides, mental position of the wet-nurse would have an influence upon the child, too (Münir, 1921: 48).

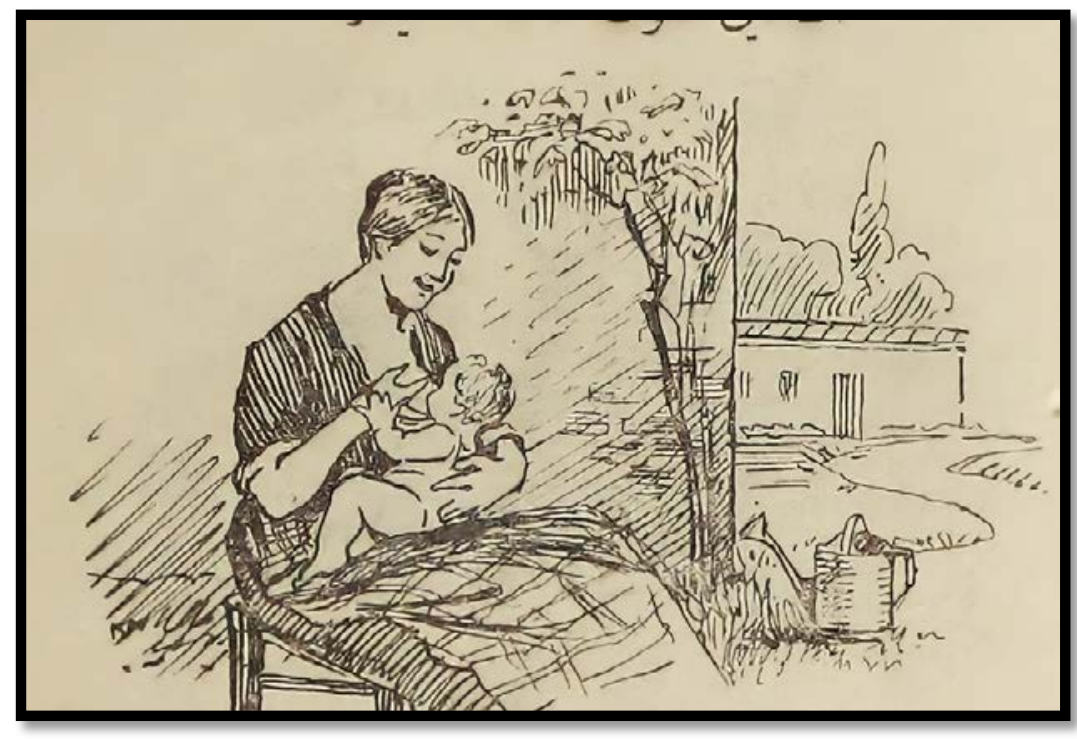

\section{“The best milk comes from mother". Source: Annelere ve Çocuklara Salnâme, (Himaye-i Etfal Cemiyeti, 1927: 25).}

There were two kinds of wet-nursing in Ottoman society. In one of them, the wet-nurse would come to the home of family who had hired her and give a suckling the baby in front of the parents. In the latter, the parents were to hand their baby in the care of a wet-nurse in her own house. Besim Ömer [Akalın] (1902: 126) underlined the importance of the second method regarding the wellbeing of the child. Surprisingly, a recent medical research suggests that breastfeeding from the same woman may lead to consanguinity between individuals even with no blood relation, and that infants produced of a marriage 
Tender Mothers: Breastfeeding, Wetnursing, and the Limits of Social Critique From the Late Ottoman to the Early Republican Periods (1880-1930)

between two such people may therefore be at risk of specific hereditary disorders as a result of this consanguinity (Özkan v.d., 2012:1).

\section{Conclusions}

Mother's milk has a great importance throughout the history of humanity, and breast-feeding was considered as an honorable act of mothers, because the nature invested mothers with a prerogative by giving them the capacity of producing the best nutriment for their infants. Breast-feeding, perhaps, was the best way of nutrition thanks to its substantial character but some women refused to feed their babies or they had to do so for some reasons. That was to be the emergence of a social institution under the name of wet-nursing.

This new practice based on the hiring of another woman who recently gave birth. In some early cases, wet-nursing might have been practiced on a volunteering basis to help the desperate mothers, but in time, it became some sort of occupation. Wet-nursing, on the other hand, became an important tool to create dominance over women in the history of hetero-patriarchal societies. In the Ottoman example, breast-feeding makes a triangle with motherhood and wet-nursing in the sense of pronatalist policies that has been designed by the aim of creating new and healthy Ottoman citizens. Therefore, the popular literature of the day attached a great significance on this subject and produced many guidelines to set the rules of ideal motherhood all over again.

The crucial point here is that we should be aware of the fact that the medical discourses about the breast-feeding, motherhood and child care were always created by men. These articles, pamphlets or books were particularly envisioned so as to build an emotional tie between the mother and her infant. After all, it was the mother who had the capacity of giving birth and raising the future soldiers of the nation, and breast-feeding was her first duty for prolonging the infant's life. As a private act, breast-feeding had the qualification of confining the woman to the house, that is to say, to the private sphere and domesticate her by a basic duty. Thus, breast-feeding and wet-nursing morally interpreted in connection with the concept of motherhood.

In the final conclusion, breast-feeding and wet-nursing became a functional tool in redefining the limits of natural and tender motherhood in the late Ottoman and early Republican periods. As in most of the physical deeds, there was a general concensus in the intellectual circles that breast-feeding was implicit within the motherhood itself. For a mother, refusing to suckle her child while she could meant literally crossing beyond the social limits. 


\section{References}

[Akalın], B. Ö. (1320/1902). Doğururken ve Doğurduktan Sonra. İstanbul: Matbaa-yı Ahmed insan.

[Akalın], B. Ö. (1339/1923). Nüfus Meselesi ve Küçük Çocuklarda Vefiyat. İstanbul: Kanaat Matbaası.

[Akalın], B. Ö. (1892). "Mebâhis-i Sıhhiye ve Tıbbiye: Emzirme (İrza'-yı Sınâi) ve Emzik Şişeleri”, Servet-i Fünûn, C. 3, S. 57, 68-72.

[Akalın], B. Ö. (1925). Çocuk Büyütmek. İstanbul: Yeni Matbaa.

[Anday], Kadri Raşid, (1923). "Tıbbî: İslam'da Nüfus ve Çocuk”, Mihrâb, C. 1, S. 1, 16-20.

[Olcay], H. O. ve Derviş, A., (1925). "Süt Çocuklarında Vefiyat”, Birinci Milli Türk Tıp Kongresinde Kıraat Edilecek Rapor Hülasası, 1-8.

[Yaşat], Ali Vahid, (1924). Annelere: Memedeki Çocuk Nasıl Beslenir?. İstanbul: Vatan Matbaası.

“Doktorlar ve Sütnineler”, Servet-i Fünûn, (1901). C. 21, S. 541, 331-333.

“irzâ‘-yı Mâderî ile Sütana ve Hatunlarımız”, Sıhhat. (1887), C. 4, S. 8, 29-30.

“Kadri Raşid Paşa'nın Mühim Bir Konferansı - (Nüfus Artırmak , Çocuklara İyi Bakmakla Kaimdir)", Âsâr-ı Nisvan. (1925). C. 1, S. 11, 8-9.

“Küçük Çocuklarda Vefiyyata Karşı - 1: Uzun veya Kısa Yoldan Emme”, Servet-i Fünûn, (1927), C. 35, S. 157-1631, 5.

“Sıhhat'in Nasihatleri: Sütananın İntihabı Hakkındadır”, Sıhhat. (1888), C. 4, S. 23, 91.

"Tıfl-ı nev-zâdın Tegaddisi", Servet-i Fünûn, (1894), C. 7, S. 180, 370-374.

AlHreashy, F. A. (2018). "Non-maternal Nursing in the Muslim Community: A Health Perspective Review", Journal of Clinical Neonatology, C. 7, S. 4, 191197.

Allen, A. T. (2005). Feminism and Motherhood in Western Europe 1890-1970: The Maternal Dilemma. New York: Palgrave Macmillan.

Al-Quran, (1937). (Trans: Abdullah Yusuf Ali). Lahore: Kashmiri Bazar.

Altorki, Soraya, (1980). "Milk-Kinship in Arab Society: An Unexplored Problem in the Ethnography of Marriage", Ethnology, C. 19, S. 2, 233-244.

Apple, R. D. (1987). Mothers and Medicine: A Social History of Infant Feeding, 18901950. Wisconsin: The University of Wisconsin Press.

Bawany, M. H., Milhan, A. ve Padela, A. I. (2016). "The Unbreakable Relationship: Are Muslims Aware of the Islamic Bioethical Perspectives on Human Breast Milk Banking?", Islamic Horizons, 48-51.

Borst, C. G. (1995). Catching Babies: The Professionalization of Childbirth, 18701920. Londra: Harvard University Press.

Bouhdiba, A. (2008). Sexuality in Islam. Londra ve New York: Routledge Press.

Brown, P. (2004). Eve: Sex, Childbirth and Motherhood Through the Ages. Chicester: Summersdale Publishers.

Carter, P. (1995). Feminism, Breasts and Breast-Feeding. Londra: Palgrave Macmillan. 
Tender Mothers: Breastfeeding, Wetnursing, and the Limits of Social Critique From the Late Ottoman to the Early Republican Periods (1880-1930)

Cassidy, T. M. ve El Tom, A. (2015). "Introduction", Ethnographies of Breastfeeding Cultural Contexts and Confrontations (Eds. Tanya Cassidy ve Abdullahi El Tom). Londra: Bloomsbury Academic.

Coulson, N. J., (1971). Succession in the Muslim Family. Cambridge: Cambridge University Press.

Fahri, M. (1318/1900). "Musâhabe: Sütnine Hanım ve Çocuk”, ikdam, C. 7, S. 2314, 3.

Foucault, M. (1978). The History of Sexuality 1: An Introduction (Trans: Robert Hurley). New York: Pantheon Books.

Foucault, M. (1982). "The Subject and Power", Critical Inquiry, C. 8, S. 4, 777-795.

George, D., Gonsenhauser, I., ve Whitehouse, P. (2006). "Medical Professionalism: The Nature of Story and the Story of Nature", Professionalism in Medicine: Critical Perspectives (Eds. Delese Wear ve Julie M. Aultman). Ohio: Springer, 63-86.

Ghaly, Mohammed, (2012). "Milk Banks Through the Lens of Muslim Scholars: One Text in Two Contexts", Bioethics, C. 26, S. 3, 117-127.

Giladi, A. (1999). Infants, Parents and Wet Nurses: Medieval Islamic Views on Breastfeeding and Their Social Implications. Leiden: Brill Publishing.

Golden, J. (1996). A Social History of Wetnursing in America: From Breast to Bottle. Cambridge: Cambridge University Press.

Hays, S. (1996). The Cultural Contradictions of Motherhood. New Heaven ve Londra: Yale University Press.

Hill, G., Johnston, G., Campbell, S., ve Birdsell, J. (1987). "The Medical and Demographic Importance of Wet-Nursing", Canadian Bulletin of Medical History, C. 4, S. 2, 183-192.

Himâye-i Etfâl Cemiyeti, (1927). Annelere ve Çocuklara Salnâme. İstanbul: Ahmed insan Matbaası.

Holmes, A. S. ve Nelson, C. (1997). "Introduction", Maternal Instincts Visions of Motherhood and Sexuality in Britain, 1875-1925 (Ed. Claudia Nelson ve Ann Sumner Holmes). New York: St. Martin's Press, 1-12.

Lee, R. (2018). The Ethics and Politics of Breastfeeding: Power, Pleasure, Poetics. Toronto: University of Toronto Press.

MacClany, Jeremy, (2003). "The Milk Tie”, Anthropology of Food, C. 2 (Special Issue), $163-182$.

Maksudyan, N. (2009). "Modernization of Welfare or Further Deprivation?: State Provisions for Foundlings in the Late Ottoman Empire", Journal of the History of Childhood and Youth, C. 2, S. 3, 361-392.

Martucci, J. L., (2015). Back to the Breast: Natural Motherhood and Breastfeeding in America. Chicago ve Londra: The University of Chicago Press.

Münir, R. (1337/1921). Çocuk Beslemek. İstanbul: Evkâf-ı İslâmiye Matbaası.

Özkan, H., Tüzün, F., Kumral, A., ve Duman, N. (2012). "Milk Kinship Hypothesis in Light of Epigenetic Knowledge”, Clinical Epigenetics, C. 4, S. 14, 1-3.

Rahbari, Ladan, (2020). "Milk Kinship and the Maternal Body in Shi'a Islam", Open Theology, S. 6, 43-53. 
Rıza Bey, A. (1324/1908). “Vazife ve Mes'uliyet: Kadın”, Servet-i Fünûn, S. 901, 272. Schacht, J. (1982). An Introduction to Islamic Law. Oxford: Clarendon Press.

Stevens, E. E., Patrick, T. E. ve Pickler, R. (2009). "A History of Infant Feeding", Journal of Perinatal Education, C. 18, S. 2, 32-29.

Tekir, H. S. (2019). “Osmanlı Devleti ve Kültür Coğrafyasında Sütannelik”, Kafkas Üniversitesi Sosyal Bilimler Enstitüsü Dergisi, S. 24, 843-864.

Thorley, V. (2008). "Sharing Breastmilk: Wet Nursing, Cross-feeding, and Milk Donations", Breastfeeding Review, C. 16, S. 1, 25-29.

Tiger, L. ve Fox, R. (2017). The Imperial Animal. Londra ve New York: Routledge.

Utku, N. Ş. (2020). "Antik ve Orta Çağ'da Sütannelik: Başkasının Sütünün Biyolojik, Ekonomik ve Kültürel Kodları”, KADEM (Kadın Araştırmaları Dergisi), C. 6, S. 1, 51-112.

Wegman, M. E. (2001). "Infant Mortality in the 20th Century, Dramatic but Uneven Progress", Journal of Nutrition, S. 131, 401-408.

Wolf, J. H. (2001). Don't Kill Your Baby: Public Health and the Decline of Breastfeeding in the Nineteenth and Twentieth Centuries. Columbus: The Ohio State University Press.

Yalom, Marliyn. (2002). Memenin Tarihi (Çev. Ayşe Gün). İstanbul: Çitlembik Yayınları.

Zeki, C. (1928). Çocuk Düşürmek: Esbâbı, Tehlike ve Âkıbetleri ve Buna Mani` Olabilecek Tedâbir. İstanbul: Kader Matbaası. 